\title{
Unbalanced Respiratory Growth of Euglena
}

\author{
By J. R. COOK AND B. HEINRICH \\ Department of Zoology, University of Maine, Orono, Maine, U.S.A.
}

\author{
(Accepted for publication 6 April 1968 )
}

\begin{abstract}
SUMMARY
The respiratory physiology of Euglena gracilis grown heterotrophically on a defined medium was examined as a function of culture age when growth was supported by glucose, acetate or ethanol as sole carbon source. The endogenous rate of oxygen consumption in general paralleled that of total protein content, usually showing a steady decline through log. and stationary phases of growth. The rate of oxygen consumption stimulated by ethanol or acetate remained fairly constant during log. phase but. decreased sharply in early stationary phase. The specific activities of representative respiratory enzymes remained essentially proportional to one another and to total oxygen consumption, but the activities of malate synthase and the malic enzyme increased greatly in stationary phase glucose-grown organisms. In general, respiratory growth was out of balance with the rate of cell division but in essential balance with the rate of biosynthesis.
\end{abstract}

\section{INTRODUCTION}

In exponential increase of typical cell populations it is generally expected that the rate of DNA synthesis will equal that of cell division. Less stringent requirements exist for other biochemical fractions, however, and frequently the RNA or protein content of the 'average' cell decreases or sometimes increases over a generation, a situation referred to as 'unbalanced growth' (Barner \& Cohen, 1956). It has been reported that some species, e.g. Euglena gracilis, may exhibit unbalanced growth on some carbon sources (e.g. acetate, succinate) but essentially balanced growth on others (e.g. ethanol (Buetow \& Levedahl, I962; Wilson \& Levedahl, 1964). In unbalanced growth the average unicellular alga will be usually larger in stationary phase than during log. phase growth; presumably these patterns come full cycle during the lag period. It is of some interest to know whether higher orders of metabolic activity are subject to the same degree of control-or lack of it-in balanced or unbalanced growth. Tissue and organ differentiation, for example, must represent an extreme case of unbalanced growth at nearly all levels of cellular activity. The problem has received little attention at the cell level. The subject of the present report is a study of respiratory growth of E. gracilis as a function of culture age. Since oxygen consumption is the terminal step in a complex, but relatively well-known and easily monitored sequence of events, it was felt that such information might be conveniently compared with changes in the biochemical profile of Euglena, and at the same time referred to a somewhat higher degree of organization than 'total protein'. The oxygen requirements of $E$. gracilis are greatly dependent on the exogenous carbon source; some (acetate, ethanol) stimulate oxygen consumption considerably above the endogenous rate, while others (e.g. glucose) cause no stimulation (Cook \& Heinrich, 1965; Danforth, I953). We 
have examined the problem of balanced versus unbalanced respiratory growth of $E$. gracilis grown on each of these three substrates. Particular attention was paid to enzymes of the glyoxylate cycle, since these are characteristically induced by the 2-C compounds and are also correlated with high oxygen consumption by Euglena (Cook \& Carver, 1966). In general, it was observed that respiratory growth was in essential balance with biosynthesis of protein, but not with cell division; some exceptions were found.

\section{METHODS}

Euglena gracilis strain $\mathrm{z}$ was used throughout. Axenic cultures were grown in the dark on a salt medium (Cramer \& Myers, 1952) with carbon sources glucose, acetate or ethanol present initially at $0.03 \mathrm{M}$. Ethanol was aseptically added to the media after autoclaving; acetate and glucose were autoclaved as a part of the media. This medium is initially buffered with ammonium and potassium phosphates at $\mathrm{pH} \mathrm{6.8}$; some caramelization of glucose occurred during autoclaving at this $\mathrm{pH}$ value, but control studies showed that this had no effect on growth rate. Ammonium phosphate also served as the sole nitrogen source. When required, the $\mathrm{pH}$ value was adjusted with $\mathrm{H}_{2} \mathrm{SO}_{4}$. The vitamins $\mathrm{B}_{1}$ and $\mathrm{B}_{12}$, necessary nutrients for $E$. gracilis $\mathrm{z}$, were autoclaved with the media.

Culture vessels were Pyrex cylinders of $1 \cdot 5$ or 3.01 . capacity, fitted with a Pyrex jacket through which water at $30^{\circ}$ was circulated. Cultures were stirred with a tefloncovered magnetic bar, and air sterilized by filtration through cotton-wool was bubbled from the bottom of the vessels. Samples were removed from the vessels by simple siphon devices. The culture volumes were sufficiently large to permit repeated analyses of a single culture over an entire growth curve. In one part of the work, a series of Erlenmeyer flasks containing acetate media were inoculated and grown in the dark at $30^{\circ}$ without agitation or forced aeration; the organisms were then harvested at different times for analysis. While this approach offered less control than the larger cultures harvested sequentially, as shown below, both approaches yielded the same sort of data.

Counts of organisms were made with the Coulter cell counter. The $\mathrm{pH}$ values of the media and of samples of organism suspensions were measured with a Beckman Zeromatic $\mathrm{pH}$ meter.

Total cell protein was measured by a microbiuret method (Goa, 1953), with known numbers of euglenas (I to $3 \times 10^{6}$ ) which had been previously washed and twice extracted with boiling ethanol. Ribonucleic acid (RNA) was estimated by the Ogur \& Rosen method (1950), by using a known number of euglenas ( $\mathrm{I}$ to $3 \times 10^{6}$ ) extracted with lipid solvents and twice briefly with cold $5 \%(\mathrm{w} / \mathrm{v})$ perchloric acid (PCA), followed by overnight digestion in $5 \% \mathrm{PCA}$ in the refrigerator. Two washes with $5 \% \mathrm{PCA}$ were added to this extract and the combined extracts, made up to volume, were read at 260 and $315 \mathrm{~m} \mu$ with the Beckman DB spectrophotometer. The difference was used to calculate total RNA, using the equation $\left(E_{260}-E_{315}\right) \times 33 \cdot 2=\mu \mathrm{g}$. RNA $/ \mathrm{ml}$. In one experiment, DNA and RNA were estimated with the Schmidt \& Thannhauser (1945) technique.

Dry mass was measured directly by drying a known number of washed euglenas in a tared aluminium dish at $80^{\circ}$, and weighing on a semimicro balance. Oxygen consumption was determined with a Clark electrode and graphically recorded. Organisms were 
washed three times with water and suspended in the salt medium without substrate. This suspension was then placed in a water-jacketed reaction vessel and flushed with air. After equilibration to $30^{\circ}$, the Clark electrode was fitted into the suspension so as to make the vessel air-tight. The suspension was stirred with a magnetic bar. Oxygen consumption was recorded for a length of time adequate to ensure linearity (about Io min.), to yield the endogenous rate of respiration. The substrate which had supported growth was then added, and respiration again recorded. At the end of such a run, a sample was removed for counting the organisms.

Respiration measurements were made in the dark, since it has been established that greening of Euglena can cause a significant decrease of oxygen consumption, at least when acetate is the carbon source (Cook, 1965). Organisms were briefly exposed to dim room light during washing; this degree of exposure was without effect on respiration. Also, suspension of the washed euglenas in fresh salt medium represented a change in $\mathrm{pH}$ value; the fresh medium was at $\mathrm{pH} 6 \cdot 8$, and the $\mathrm{pH}$ value of the growth medium varied with culture age (see below). However, it has been shown that $\mathrm{pH}$ changes in this range have no immediate effect on the oxygen consumption of Euglena grown with these substrates (Cook \& Heinrich, 1965). The Clark electrode was calibrated with air-flushed and nitrogen-flushed water at $30^{\circ}$ immediately before a run, to permit calculation of absolute amounts of oxygen consumed.

Organisms for enzyme analyses were washed three times with water and suspended in $4 \mathrm{ml} .0 .02 \mathrm{M}$-tris buffer ( $\mathrm{pH} \mathrm{8}{ }^{\circ} \mathrm{o}$ ), brought to $0^{\circ}$, and homogenized with the French press at $2000 \mathrm{lb}$./sq.in. at 0 to $4^{\circ}$. In some cases the crude homogenate was used directly, in other cases the supernatant fluid after centrifugation at $10,000 \mathrm{~g}$ at 0 to $2^{\circ}$ was used for assay. In a given experiment, however, the method taken was consistent; for example, malate synthase activity over the growth curve in glucose-grown Euglena was always estimated in the supernatant fluid after centrifugation, while malate synthase activity over the growth curve of acetate-grown Euglena was always measured in crude homogenate. While this gave some absolute differences between experiments, the nature of the comparisons to be made did not make this important.

All enzyme assays were made spectrophotometrically at $25^{\circ}$. Enzymes studied included malate synthase (E.C. 4.I.3.2), malic enzyme (E.C. I.I.I.40), isocitric dehydrogenase (E.C. I.I.I.4I), aconitase (E.C. 4.2.I.3), and malic dehydrogenase (E.C. I.I.I.37). Details of the assays used were described previously (Heinrich \& Cook, 1967). For malate synthase, one enzyme unit is that amount which converts I $m \mu$ mole acetyl-CoA/min.; for the others, an enzyme unit is that amount causing an extinction change of $0.0 \mathrm{I} / \mathrm{min}$. Specific activities are expressed as enzyme units $/ \mathrm{mg}$. protein. Protein content was estimated by the phenol method of Lowry, Rosebrough, Farr \& Randall (195I), with either the crude homogenate or the supernatant fluid after centrifugation.

The population density of a culture was followed from inoculation. When the population had reached a density compatible with the analyses to be made $(20,000-$ 50,000 organisms $/ \mathrm{ml}$.), the culture was sampled for the first series of measurements. The count of organisms and the $\mathrm{pH}$ value of the sample were determined, and then the organisms centrifuged down, washed, and suspended in the salt medium for respiration measurement. The organisms were then washed again and divided into 3 or 4 portions, for enzyme analyses and protein, nucleic acids and dry mass determinations (the latter three measurements were done in triplicate at each sampling time). Usually 
samples were taken at intervals of about one generation which was about $\mathrm{I} 2 \mathrm{hr}$ under the conditions used. About $2 \mathrm{hr}$ were required in handling the organisms at sampling when all analyses were made.

\section{RESULTS}

\section{Changes in $p H$ value of cultures}

Figure I shows typical growth and $\mathrm{pH}$ curves for Euglena gracilis $\mathrm{z}$ under the conditions used here, with acetate, ethanol or glucose as sole carbon and energy source. Growth on glucose resulted in a lower $\mathrm{pH}$ value and growth on acetate a higher $\mathrm{pH}$ value; the reaction with growth on ethanol showed a very slight decrease of $\mathrm{pH}$ during log. phase, a little more pronounced decrease in early stationary phase, and with a $\mathrm{pH}$ increase as stationary phase progressed. It is difficult to assess the cause of these $\mathrm{pH}$ changes. In a phosphate-buffered medium, with ammonium phosphate as sole nitrogen source, removal of ammonia during growth would cause a net decrease in $\mathrm{pH}$ value if the carbon source were not charged. Growth with glucose resulted in a greater decrease in $\mathrm{pH}$ value than did growth with ethanol, suggesting that acidic byproducts were formed with glucose. Acid production has been used to show whether micro-organisms metabolize carbohydrates fermentatively or oxidatively (Hugh \& Leifson, 1953). However, no radioactive compounds other than glucose were detected by chromatography of the medium after long-term culture of Euglena with radioactive glucose (Belsky, I955). The excretion of volatile acidic compounds was not excluded. Incorporation of acetate as the undissociated acid could account for the alkaline reaction occurring during growth on this substrate, assuming the incorporation occurred at a rate greater than the removal of ammonia. Pringsheim \& Wiessner (1960) used this $\mathrm{pH}$ increase as a measure of acetate utilization by Euglena.

The final population density attained by Euglena gracilis $\mathrm{z}$ was much lower when acetate was sole carbon source than with glucose (Cook \& Heinrich, 1965) or ethanol, although ethanol-grown and acetate-grown Euglena have essentially the same physiological profile (Buetow \& Padilla, 1963). Dr W. Danforth (personal communication) noted that acetate yielded higher population densities when growing cultures were periodically acidified. Our measurements confirmed this; the final population densities increased as the initial $\mathrm{pH}$ was decreased: ( $\mathrm{pH}$ : population $/ \mathrm{ml}$.) $6 \cdot 8,250,000 ; 6 \cdot 0$, 300,$000 ; 5^{\circ} 0,400,000 . \mathrm{pH} 5 \cdot 0$ is the lower limit for growth of Euglena on acetate (Wilson, Buetow, Jahn \& Levedahl, I959; Cook \& Heinrich, 1965).

Dean \& Hinshelwood (I959) discussed the changes of $\mathrm{pH}$ value which occur during growth in batch culture. They concluded that enzyme content often appears to be affected not directly by the $\mathrm{pH}$ value of the medium, but by other factors which come into being concomitantly with the $\mathrm{pH}$ change. In the case of $\mathrm{pH}$-limited growth on acetate, the simplest explanation would appear to be one of permeability (Wilson et al. 1959). In any event, the $\mathrm{pH}$ value of the medium need not reflect the $\mathrm{pH}$ value of the interior of the organism. As seen below, the specific activity (and total amount) of most of the enzymes studied here did not appear to be affected by the $\mathrm{pH}$ value of the medium. In the present context, the $\mathrm{pH}$ changes during the growth cycle apparently became limiting for growth with acetate but not with ethanol or glucose. 


\section{Endogenous respiration}

A brief definition of endogenous respiration may be made here. The oxygen consumption of washed cells varies with the time after washing; most published studies with Euglena (including this paper) report this respiration measured immediately after washing. Wilson \& Danforth (1958) argued that this endogenous oxygen consumption continues after addition of the exogenous carbon source (acetate or ethanol in their studies), and that the true oxygen consumption stimulated by the carbon source can be derived only by subtracting the endogenous value. This practice is followed here.

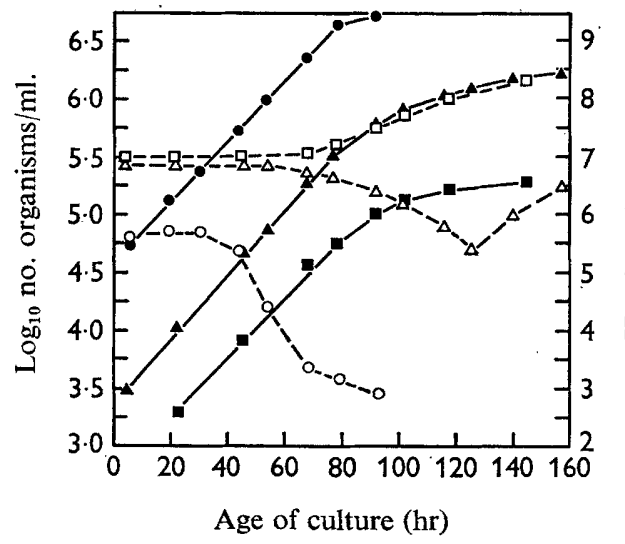

Fig. I

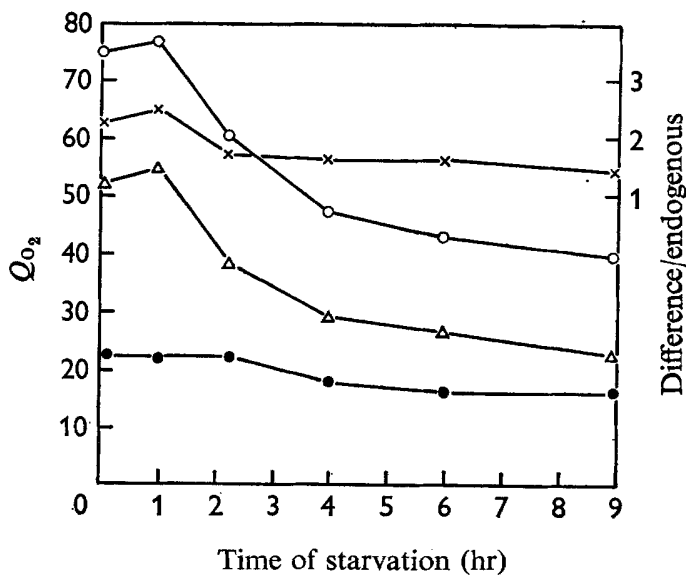

Fig. 2

Fig. I. Euglena gracilis $\mathrm{z}$ : change in culture $\mathrm{pH}$ as a function of culture age. Filled symbols, log. no. organisms/ml.; open symbols, culture $\mathrm{pH}$. Carbon sources supporting growth were: glucose (circles), ethanol (triangles), acetate (squares).

Fig. 2. E. gracilis z. Changes in the rate of oxygen consumption after washing organisms at time o. The filled circles show the endogenous $Q_{\mathrm{O}_{2}}$, and the open circles the $Q_{\mathrm{O}_{2}}$ after the addition of the growth substrate ethanol. The triangles show the differences between these two rates, i.e. the oxygen consumption stimulated by ethanol. Crosses show the ratio of respiration due to ethanol to the endogenous.

Figure 2 shows the change in the endogenous respiration value, the rate of oxygen consumption in presence of ethanol, and the difference between the two, as a function of time after washing. The Euglena gracilis $\mathrm{z}$ organisms were grown with ethanol as sole carbon source, harvested in log. phase, washed, and incubated with forced aeration in the growth medium without ethanol. Samples of the suspension were removed periodically for measurement of endogenous respiration, after which ethanol was added to measure the degree of stimulation by substrate. The endogenous rate was unchanged for the first $2 \mathrm{hr}$. Stimulation of respiration by ethanol increased slightly after I hr, but the increase ( 2 to $3 \%$ ) was probably not significant. Since all other respiratory studies reported here were completed within 30 to $45 \mathrm{~min}$. of harvest, they have been accepted as representative of oxygen consumption during growth.

Total oxygen consumption in presence of ethanol was 2.5 to 3.5 times greater than the endogenous value; the difference curve therefore has the same general shape as total respiration with ethanol (Fig. 2). Quantitative variations between the endogenous 
and the difference curve during starvation are obvious; the endogenous rate was constant for the first $2 \mathrm{hr}$, while the difference rate decreased almost $30 \%$ between the first and second hour of starvation. After $9 \mathrm{hr}$, the endogenous rate had decreased about $30 \%$, while the oxygen consumption stimulated by ethanol (the difference curve) had decreased about $55 \%$. This quantitative variation is perhaps best shown in the ratio [difference rate/endogenous rate], which is also plotted in Fig. 2. The rate of oxygen consumption stimulated by ethanol decayed much more rapidly than the endogenous rate. A similar phenomenon was observed when cultures were allowed to grow into stationary phase, probably for the reason to be discussed below.

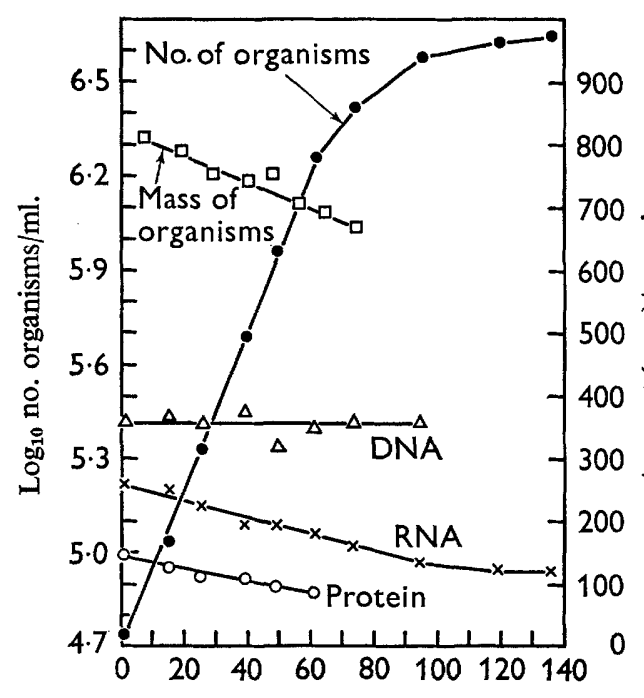

Age of culture (hr)

Fig. 3

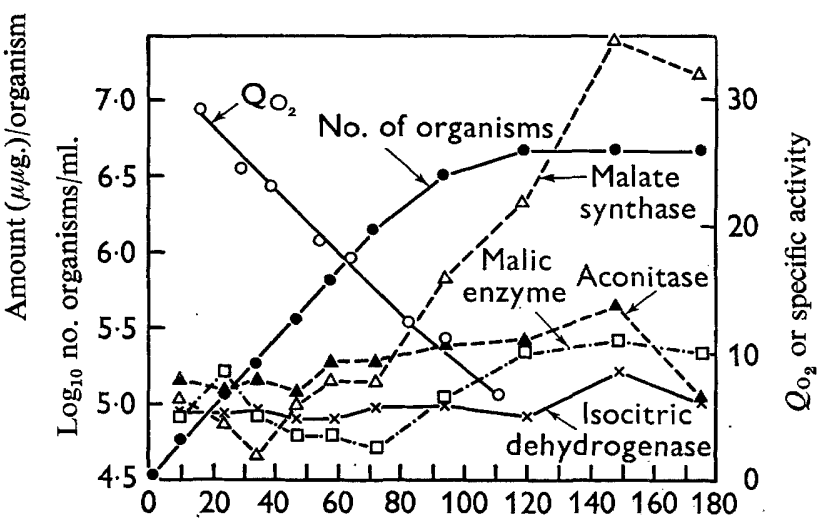

Age of culture (hr)

Fig. 4

Fig. 3. Biochemical profile of the average Euglena gracilis $\mathrm{z}$ organism as a function of culture age; glucose as sole carbon source. To facilitate plotting, observed values for RNA were multiplied by 10 and those for DNA by 100 .

Fig. 4. E. gracilis $z$. Changes in respiration and the specific activity of representative respiratory enzymes as a function of culture age, with glucose as sole carbon source. The $Q_{\mathrm{O}_{2}}$ decreased steadily. Malate synthase and the malic enzyme showed signicant changes in activity.

\section{Growth on glucose}

The results with Euglena gracilis $\mathrm{z}$ cultured with glucose as sole carbon source are summarized in Figs. 3 and 4. Figure 3 shows that protein, RNA, and total dry mass/ organism decreased through log. phase and early stationary phase, at proportionate rates. The doubling time for number of organisms was $12.0 \mathrm{hr}$; in this time the average organism showed a decrease of about $10 \%$ in mass, etc. The rate of cell division exceeded that of biosynthesis by about $10 \%$. The DNA content, within experimental error, was, however, constant. These data confirm and extend those obtained by Wilson \& Levedahl (1964) with Euglena grown with ethanol, succinate, or acetate.

Figure 4 shows the rate of oxygen consumption $\left(Q_{\mathrm{O}_{2}}, \mu \mathrm{l} . \mathrm{O}_{2} / \mathrm{hr} / 10^{6}\right.$ organisms $)$ and the specific activities of representative respiratory enzymes as a function of culture 
age. The $Q_{0_{0}}$, which was about 30 in early log. phase, decreased continuously to nearly 5 in early stationary phase. The doubling time for organism numbers was $13.3 \mathrm{hr}$, and the $Q_{\mathrm{o}_{3}}$ decreased about $\mathrm{I} 5 \%$ in each generation. Glucose does not stimulate respiration significantly above the endogenous value (Cook \& Heinrich, 1965), and these data, therefore, represent the respiratory rate both in absence and in presence of glucose.

Specific activities of the respiratory enzymes were essentially constant during log. phase growth. Since the activities are referred to protein content, this must mean that the total amount of these enzymes contained within the average organism must also have been decreasing with culture age. The specific activity of the two enzymes malate synthase and the 'malic enzyme' showed a marked increase beginning in early stationary phase. Since the total cell protein did not increase, it is inferred that the 'functional' concentration of these two enzymes was increased at this time. Whether this apparent increase was due to a true induction of enzyme synthesis or to a decreased degree of inhibition cannot be ascertained from these data. The data suggest a shift of metabolic emphasis, from a typical Krebs cycle oxidation of carbohydrates to utilization of fats. Metabolism of fat reserves in micro-organisms characteristically induces operation of the glyoxylate cycle (Kornberg, 1959). The supposition of a shift to fat metabolism is reinforced by the fact that the respiratory quotient of glucosegrown Euglena was about $\mathrm{I} \cdot 0$ during log.-phase growth, but decreased as low as 0.3 in stationary phase (Heinrich \& Cook, 1967).

\section{Growth on ethanol}

With ethanol as sole carbon and energy source growth of Euglena gracilis $\mathrm{Z}$ was unbalanced in either a positive or negative direction. In one experiment the protein content of the average organism showed a slight increase during middle log. and early stationary phase (Fig. 5); the increase per organism amounted to about $7 \%$ in a single generation. This experiment was terminated in very early stationary phase, but the average protein content tended to a constant value in late log. and early stationary phases. In two other experiments (also summarized in Fig. 5) the protein content of the average organism decreased during log. and early stationary phase, but remained constant throughout late stationary phase. While similar trends in protein content were found in two of these experiments, great variation existed in absolute amounts of protein per organism. The maximum amount found in any given experiment was $35^{\circ}$, the second largest $3 \mathrm{IO}$, and the largest amount found in the third experiment was $250 \mu \mu \mathrm{g}$./organism. This sort of discrepancy can probably be explained only by the past history of the organisms. In the present case, all the cultures had been previously adapted to growth on ethanol, and trends in protein content were most likely a result of culture age at inoculation, a condition which was not rigorously controlled in these experiments. The role of the lag period in balanced or unbalanced growth has not been adequately studied with any protozoan cell, although it is known that the length of the lag period increases with time spent in log. and stationary phases of growth (Prescott, 1957). In the present work, inoculations were always made with adapted organisms in log. or early stationary phase growth. In one of these experiments with ethanol-grown Euglena gracilis z RNA values were followed and were essentially parallel to the protein content (Fig. 5).

Respiration as a function of culture age of Euglena gracilis $\mathrm{z}$ grown with ethanol 
was followed in two experiments (see Fig. 6). Under our cultural conditions, stationary phase growth with ethanol usually started at 0.5 to $\mathrm{I} \times 10^{6}$ organisms $/ \mathrm{ml}$. The endogenous respiration value of washed organisms showed a steady decrease throughout log. and stationary phase, from a value of about $25 \mu \mathrm{l} . / \mathrm{hr} . / 10^{6}$ organisms to a low value of 10 or less in stationary phase. Respiration values in presence of ethanol showed less tendency to decrease; indeed, the respiration stimulated by ethanol (i.e. above the endogenous value was very nearly constant during log.-phase growth, in one case showing an average decrease of only $2-3 \%$ in one generation and in another case showing a slight increase during log. and early stationary phases of growth. The respiration stimulated by ethanol, however, decreased rapidly as the stationary phase progressed, much more rapidly than the decrease observed in the endogenous rate (Fig. 6).

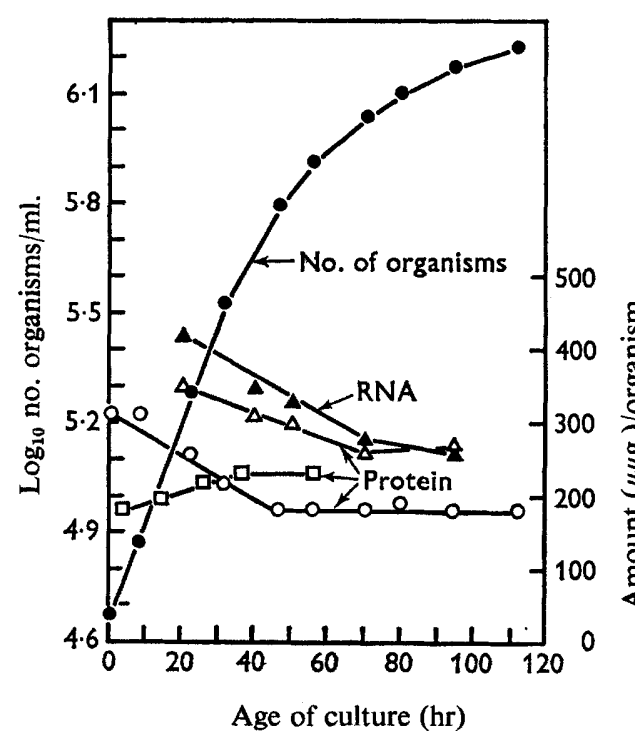

Fig. 5

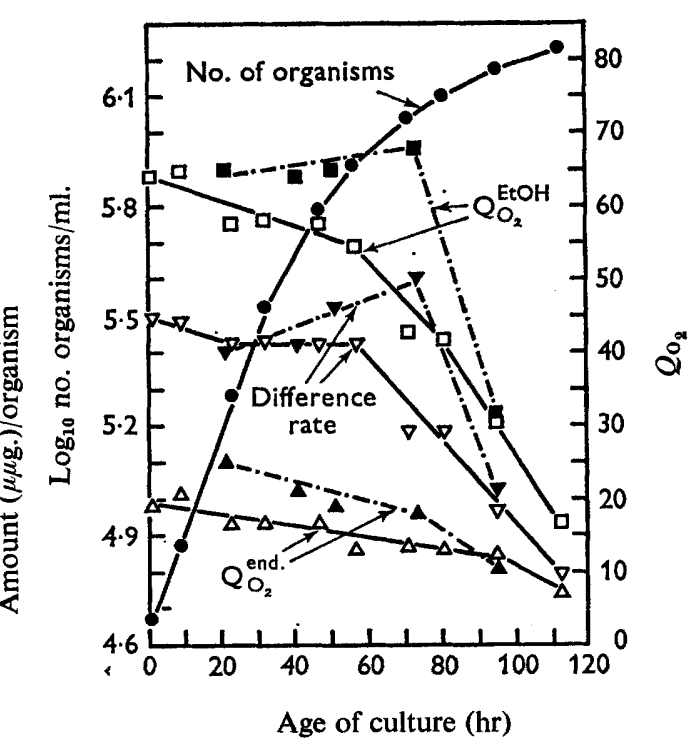

Fig. 6

Fig. 5. Changes in protein and RNA content of the average Euglena gracilis $\mathrm{z}$ organism as a function of culture age; ethanol as sole carbon source. A representative growth curve is shown; protein values were followed in three separate experiments. In one case, RNA levels (A) were also followed.

Fig. 6. E. gracilis z. Rate of oxygen consumption as a function of culture age; ethanol as carbon source. Two experiments shown, as indicated by open or closed symbols, with a representative growth curve $(\bullet)$. Endogenous respiration rates are shown by $\Delta, \Delta$, respiration in the presence of ethanol by $\square, \mathbf{a}$; and the difference between these two rates by $\nabla, \nabla$.

Activities of representative respiratory enzymes in ethanol-grown Euglena gracilis $\mathrm{Z}$ are shown in Fig. 7. Isocitric dehydrogenase and malic dehydrogenase had constant specific activities during log. and early stationary phase, and the malic enzyme showed an increase in early stationary phase. These are patterns similar to those found with glucose-grown Euglena. Malate synthase, important in growth on C-2 compounds, showed constant high activities throughout log. phase. These assays were made on samples from the same culture that showed a steadily increasing protein content (Fig. 5); from this it may be assumed that at least a part of the total respiratory com- 
plement was unbalanced with division in a positive direction. Unfortunately, our oxygen sensing equipment was inoperative during this run and no correlation could be made with total oxygen consumption.

\section{Growth on acetate}

According to Wilson \& Levedahl (1964), culture of Euglena gracilis $\mathrm{z}$ on acetate gave 'more' unbalanced growth than was observed with ethanol, i.e. the average organism became smaller with each generation when acetate was sole carbon source. We confirmed this in the usual case; in three or four experiments, protein concentrations in the average organism decreased about $6 \%$ in a generation. A typical experiment is summarized in Fig. 8, which also shows how the rate of endogenous respiration decreased through log and early stationary phase. Oxygen consumption by the average

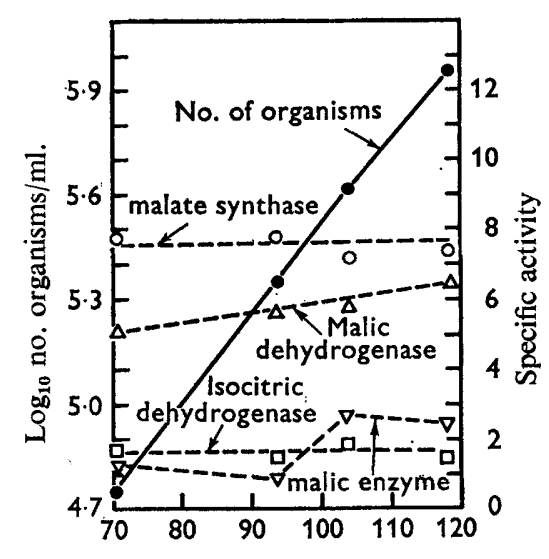

Age of culture (hr)

Fig. 7

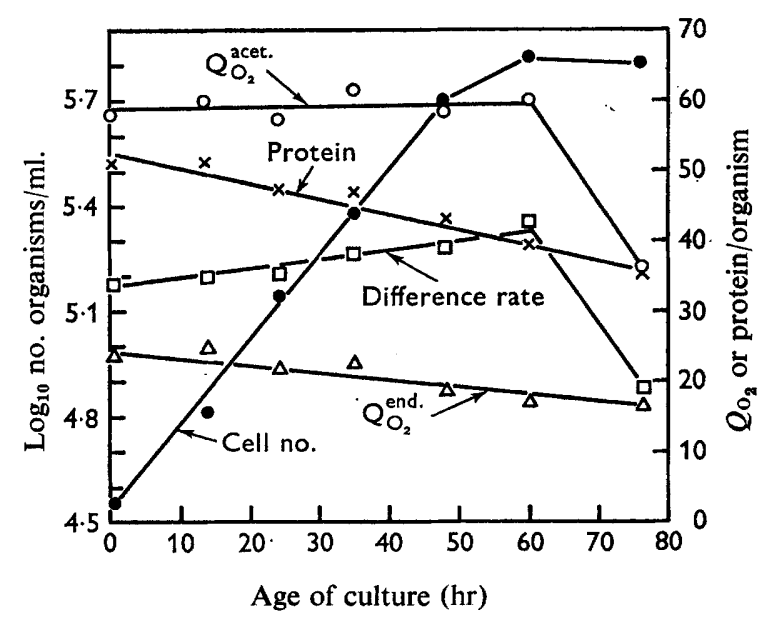

Fig. 8

Fig. 7. Euglena gracilis z. Specific activity of representative respiratory enzymes as a function of culture age; ethanol as carbon source. To facilitate graphing, activities for the malic enzyme and malate synthase were multiplied by $0^{\circ} I$ and those for malic dehydrogenase (MDH) by 0.01 ; those for isocitric dehydrogenase (IDH) are as indicated on the ordinate. Number of organisms $(\bullet)$ had reached early stationary phase by end of the experiment, and the malic enzyme activity showed an increase at this time; malate synthase activities were high over the entire growth curve, with no significant change at any time.

Fig. 8. E. gracilis $\mathrm{Z}$. Protein content and rate of oxygen consumption as a function of age of organisms; acetate as sole carbon source. Protein $(x)$ and the endogenous respiration rate $(\triangle)$ decreased steadily throughout log. and stationary phases; oxygen consumption in the presence of acetate $(O)$ constant during log. phase, but decreased sharply in stationary phase. The oxygen consumption actually stimulated by acetate $(\square)$ increased steadily during log. phase and decreased only in stationary phase. Observed values for protein content were ro times greater than indicated on the ordinate.

organism in presence of acetate remained essentially constant, but with a precipitous decrease in early stationary phase. The rate of oxygen consumption actually stimulated by acetate (the 'difference' rate) increased slightly through log. phase growth, and showed a marked decrease coincident with the beginning of the stationary phase.

In one experiment with an acetate culture, a bathtub caulking compound was used to seal some of the supply lines. While none of the sealer came in direct contact with 
the medium, some of its components were apparently volatile and inhibited division of Euglena gracilis z; decrease of the growth rate began at populations of 40,000 to 50,000 organisms $/ \mathrm{ml}$, rather than at the usual 200,000 to 400,000 organisms $/ \mathrm{ml}$. (see Fig. 8). While the behaviour of $E$. gracilis $\mathrm{z}$ in the presence of the inhibitor(s) is not to be regarded as typical, the experiment was instructive and is summarized in Fig. 9. The protein content of the average organism increased through the log. and early stationary phases to high values -2 to 3 times that of the 'typical' organism-and remained high into late stationary phase. The endogenous respiration rate, instead of decreasing, was constant or showed a slight increase over the whole period. Oxygen consumption stimulated by acetate increased steadily throughout log. phase and most of the stationary phase, showing the characteristic decrease only in very late stationary phase. The specific activity of the malic enzyme increased ten-fold over the whole period observed (cf. a comparable change in glucose-grown Euglena, Fig. 4), and remained high even in late stationary phase. The specific activity of malate synthase decreased slightly in early stationary phase, remained constant over most of stationary phase, and decreased rapidly in late stationary phase. An estimate of the total amount of these two enzymes in $E$. gracilis $\mathrm{z}$ can be made by multiplying the specific activities by total cell protein. For clarity this curve is not shown in Fig. 9, but this estimate of the total amount of malate synthase, which catalyses an anaerobic reaction, paralleled total oxygen consumption stimulated by acetate.

In all the above experiments Euglena gracilis $\mathrm{z}$ was grown in vigorously aerated vessels, and in general the rate of respiration decreased with culture age. In another series of experiments, in which the organism was grown in static Erlenmayer flasks with acetate medium having a surface:volume ratio adequate for optimal growth, the $Q_{\mathrm{O}_{2}}$ increased with culture age much like the experiment shown in Fig. 9, approaching IOO $\mu \mathrm{l} . / \mathrm{hr} . / \mathrm{IO}^{6}$ organisms in late $\mathrm{log}$. phase before decreasing. This positive sort of unbalanced growth was qualitatively reproducible and appeared to be a result of the different growth conditions. Oxygen consumption by $E$. gracilis $\mathrm{z}$ grown with acetate was high. It seems likely that a continuously decreasing oxygen tension in the medium as a result of increasing population density could cause a response toward higher respiratory capacity. Such adaptations were found by Gray, Wimpenny, Hughes \& Mossman (1966) with Escherichia coli grown in different oxygen tensions. This sort of unbalanced growth of $E$. gracilis $\mathrm{z}$ would appear to differ fundamentally from most of the results reported in this paper, in which oxygen was not a limiting factor.

\section{Changes during the lag period}

In most of the results described above, the average size of the organisms (based on protein, RNA, or mass) decreased during the log. phase; an exception was the one case where division but not growth was inhibited (see Fig. 9). The average size decreased less during growth with ethanol than with glucose or acetate, but on each substrate the decrease continued into stationary phase. It might be inferred that the lag phase must show an opposite trend, i.e. growth without division. The time course of these changes was followed in cultures of Euglena gracilis $\mathrm{z}$ grown with ethanol or glucose, diluted from stationary phase to population densities compatible with the assays which were done. Figure Io shows changes in the biochemical profile of $E$. gracilis $\mathrm{z}$ following dilution of a stationary-phase glucose culture with fresh medium. There was a lag of about $20 \mathrm{hr}$ before the rate of number increase became exponential, more than half of 
this time with no significant increase in number. There was no evidence of any 'inoculation synchrony'. Upon dilution, however, there was an immediate increase in RNA content, followed shortly by an increase in total cell mass; protein content, on the other hand, remained static until division began. Thereafter, the average protein content steadily increased during early log. phase before a decline set in. This is one of the few circumstances where a strict correlation between the RNA and protein content of $E$. gracilis $\mathrm{z}$ was not found. In normal log.-phase growth the ratio RNA:protein remains fairly constant under a wide variety of culture conditions (Cook, I966). In the present case in lag phase, however, RNA synthesis clearly preceded the initiation of protein synthesis, and total cell mass approximately paralleled RNA rather than protein content during this transition period. In E. gracilis z the major fractions of total mass are proteins, fats and the polysaccharide paramylum. It is inferred that in the lag period also there was an accumulation of fats or polysaccharides. It may

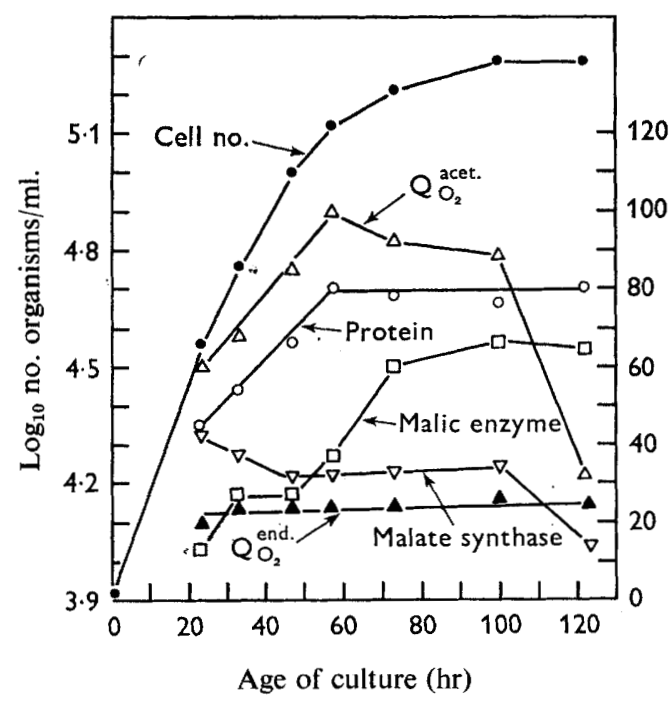

Fig. 9

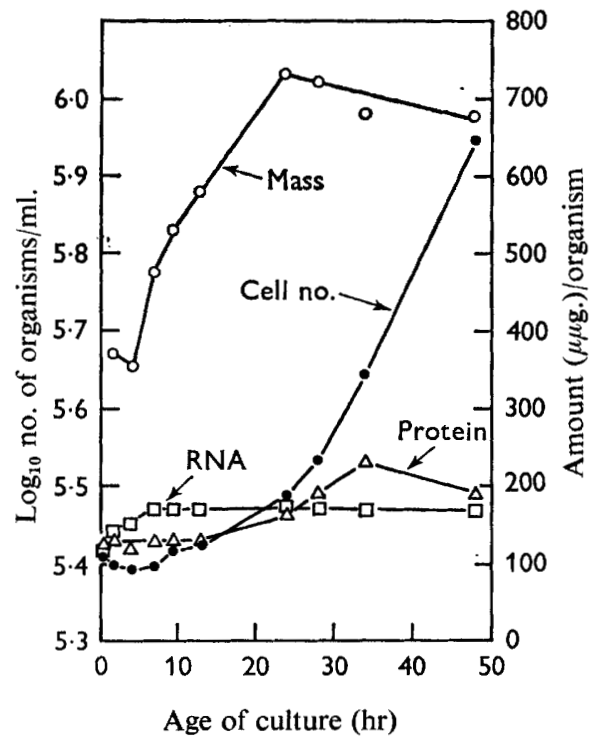

Fig. Io

Fig. 9. Euglena gracilis z. Atypical experiment with acetate as sole carbon source. Division was inhibited very early by an unknown component of a sealing material, which entered the culture (the experiment shown in Fig. 8 can be taken as typical). The protein content of the average organism $(O)$ almost doubled before inhibition was complete; the $Q_{\mathrm{O}_{2}}$ in the presence of acetate $(\triangle)$ showed a parallel increase, decreasing only in later stages of inhibition. The specific activity of malate synthase, referred to total protein, showed a slight early decrease, but was stable during most of the time, reflecting an increase in the total amount of this enzyme. The specific activity of the malic enzyme increased steadily except in the later stages of inhibition. Values for protein were to times greater than indicated on the ordinate.

Fig. Io. Changes in the biochemical profile of stationary-phase E. gracilis $\mathrm{z}$ following dilution with fresh media; glucose as sole carbon source. Dilution at time 0 , from $4 \times 10^{6}$ organisms/ ml. RNA values (multiplied by 10 to facilitate graphing) increased well before those of protein.

be noted from Fig. Io that the maximum amounts of RNA and protein attained in early log. phase glucose-grown E. gracilis $\mathrm{z}$ were less than those shown in Fig. 3. The experiment described in Fig. Io started with an initial population of 250,000 organisms/ 
$\mathrm{ml}$; that in Fig. 3 with less than I0,000 organisms $/ \mathrm{ml}$. A comparison of these two experiments indicates that positive unbalanced growth, i.e. increased average size of organisms with culture age, occurred in lag and very early log. phase, but that the size of the inoculum determined when this unbalanced growth became negative in sign, and average organism size started to decrease. Whether this was due strictly to population density or to ancillary conditions, e.g. a change to different $\mathrm{pH}$ values, cannot be determined from these data.

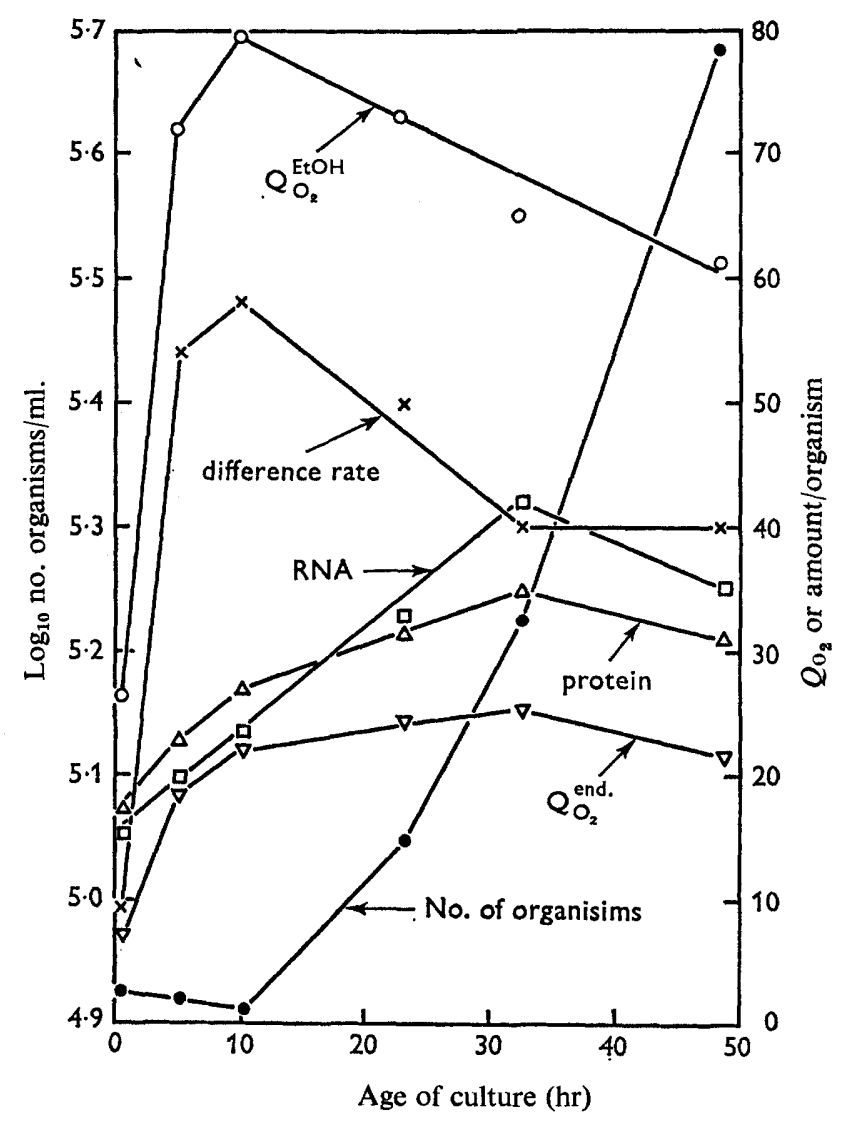

Fig. I I. Changes in the physiological profile of stationary phage Euglena gracilis $\mathrm{z}$ following dilution with fresh media; ethanol as sole carbon source. Dilution at time 0 , from $3 \times 10^{6}$ organisms/ml. RNA and protein values were essentially parallel (protein values were Io times those indicated on the ordinate). Both the endogenous rate of respiration $(\nabla)$ and that in presence of ethanol $(O)$ showed an early increase, in the lag period; the endogenous rate continued increasing into early log. phase, while the $Q_{\mathrm{O}_{2}}$ in the presence of ethanol began decreasing much earlier. The plot showing oxygen consumption actually stimulated by ethanol $(x)$ accentuated this difference.

A comparable experiment with ethanol-grown Euglena gracilis $\mathrm{z}$ is shown in Fig. I I. A lag of Io hr elapsed before division began, and protein and RNA synthesis began simultaneously immediately after dilution. (This culture had not been allowed to proceed as far into stationary phase as that described in Fig. 10, which may account for this difference.) Protein and RNA content were essentially parallel during lag and 
early log. phases. The endogenous respiration, and that with ethanol, increased very rapidly, attaining near-optimum values after 5-10 hr and before any detectable increase in number of organisms. Figure I I shows that the endogenous respiration rate went through a maximum only after the rate of division (and the protein content) had reached maximum values. The oxygen consumption stimulated by ethanol went through a maximum at about the end of lag phase, and by the time the endogenous respiration rate had reached its maximum, respiration stimulated by ethanol had already decreased some $35 \%$. This difference may be of no particular significance, but it does indicate that the endogenous respiration of $E$. gracilis $\mathrm{z}$ can be separated from that stimulated by $2-\mathrm{C}$ compounds in the lag period, perhaps even more clearly than during log.-phase growth.

\section{DISCUSSION}

Hutchens (194I) reported that the rate of oxygen consumption by Chilomonas paramecium decreased with culture age. This is in essential agreement with our findings with Euglena gracilis $\mathrm{z}$ described here. Albergoni \& Pranzetti (1963) found that the endogenous respiration of Euglena decreased during log. phase growth, and the oxidation of acetate decreased in parallel with the endogenous respiration; these organisms had been grown with glucose as principal carbon source, and the respiration stimulated by acetate was considerably less than that reported in the present work for organisms adapted to acetate. Qualitatively, however, the two sets of data are in essential agreement.

It has been recognized for some time that growth and division of cells are seldom balanced, so it is not surprising that the rate of oxygen consumption by Euglena gracilis $\mathrm{Z}$ was not constant during $\log$. and early stationary phases of growth. Respiration paralleled increase of total cell protein; under conditions where one changed, the other changed in the same direction. It may be inferred that the enzyme complement of the respiratory apparatus (which must be an important fraction of the total cell protein) was synthesized at rates roughly proportional to the total rate of biosynthesis (or limited the latter). The specific activities of the respiratory enzymes, referred to protein, were constant over most of the incubation period studied, showing variation in some cases only in late stationary phase. The one exception which was observed to this trend was in late stationary phase acetate-grown or ethanol-grown $E$. gracilis $\mathrm{z}$, when cell protein changed little but the respiration stimulated by the substrate decreased to rates approaching the endogenous value. It was possible, during growth on these two substrates, to separate the endogenous respiration from that stimulated by the substrate in more than a quantitative manner. In our best experiments, the endogenous rate showed a steady decrease while the oxygen consumption due to substrate was essentially constant over most of the log. and early stationary phases of growth. While these trends did not differ greatly, they were consistently found in seven different experiments with organisms grown on these two substrates; the ratio between the 'difference' and the endogenous rates changed with culture age. The explanation for the change in this ratio is not clear. Perhaps the metabolism of acetate and ethanol involves oxidative pathways not utilized in the oxidation of endogenous reserves. The activity of malate synthase was always proportional to oxygen consumption stimulated by acetate or ethanol, in spite of the fact that the enzyme catalyses an anaerobic reaction. This correlation held even in late stationary phase, where these substrates 
stimulated oxygen consumption very little. Possibly operation of the anaerobic glyoxylate by-pass in Euglena which is induced by 2-C compounds (Cook \& Carver, 1966), co-ordinately induces an oxygen-requiring sequence of reactions different from those associated with the classic Krebs cycle. On the other hand, late stationary phase glucose-grown $E$. gracilis $\mathrm{z}$ showed an increase in malate synthase without any concomitant increase in oxygen consumption. This change probably reflected a shift from utilization of carbohydrate to utilization of stored lipid. The respiratory quotient $\left(\mathrm{CO}_{2}: \mathrm{O}_{2}\right)$ of glucose-grown Euglena decreased from $\mathrm{I} \cdot 0$ in log. phase to about 0.3 in late stationary phase in the experiments of Heinrich \& Cook (1967).

It may be inferred from these studies that late log. phase Euglena gracilis z organisms have less oxidative energy available for growth and division than do early log. phase organisms. This is reflected in the smaller size of the organisms in the later stages of the growth curve. It is not possible from these data to say that the rate of energy transformation limits biosynthesis, or vice versa. The decreased rates of energy transformation in late log. phase were without effect on the rate of multiplication, which remained constant for extended periods during growth with ethanol or glucose. Perhaps energy used in division processes, if this should prove to be considerable and constant in amount, is stored in compartments not available for general cell growth, much as proposed in Swann's 'energy reservoir' hypothesis (1957). Reference to Fig. 3 will show that total cell protein during growth on glucose was about twice as great in early log. phase as it was in late log. phase. It is difficult to imagine that the size of the mitotic apparatus, and the energy needed to activate it, could differ by this amount when the rate of mitosis itself was unchanging. However, the protein complement of the mitotic apparatus was about 10\% of the total cell protein in sea-urchin eggs (Mazia, 1961), and might be even less in Euglena. Mazia (1961) emphasized that the energy required for cell division might be very small indeed. The magnitude of the changes in energy transformation studied here with Euglena, estimated by total oxygen consumption, may be several orders above that involved in mitosis and cytokinesis. Certainly the rate of respiration is more closely correlated with the rate of biosynthesis than with the rate of cell division.

This work was supported in part by N.I.H. Grant GN-I2I79 to the senior author and in part by a N.A.S.A. Grant (NsG-338) to the University of Maine, U.S.A.

\section{REFERENCES}

Albergoni, V. \& Pranzetti, P. (1963). Ricerche sul metabolismo ossidativo di Euglena gracilis. Studi sassar. Sezione III II, 453.

BARNer, H. D. \& CoHEN, S. S. (1956). Synchronization of division of a thymineless mutant of Escherichia coli. J. Bact. 72, II 5 .

Belsky, M. M. (1955). Studies on the utilization of glucose by the flagellate, Euglena gracilis. Diss. Abstr. 15, 678 .

Buetow, D. E. \& LeVedahL, B. H. (1962). Decline in the cellular content of RNA, protein and dry weight during the logarithmic growth of Euglena gracilis. J. gen. Microbiol. 28, 579.

Buetow, D. E. \& Padilla, G. M. (I963). Growth of Astasia longa on ethanol. I. Effects of ethanol on generation time, population density and biochemical profile. J. Protozool. ro, I 2 I.

Cook, J. R. (1965). Influence of light on acetate utilization in green Euglena. Pl. Cell Physiol., Tokyo 6, 301 .

CooK, J. R. (1966). Adaptations to temperature in two closely related strains of Euglena gracilis. Biol. Bull. mar. biol. Lab., Woods Hole 131, 83. 
COOK, J. R. \& CARver, M. (1966). Partial photo-repression of the glyoxylate by-pass in Euglena. Pl. Cell Physiol., Tokyo 7, 377.

Cook, J. R. \& HeInRICH, B. (1965). Glucose vs. acetate metabolism in Euglena. J. Protozool. 12, 581.

Cramer, M. \& Myers, J. (1952). Growth and photosynthetic characteristics of Euglena gracilis. Arch. Mikrobiol. 17, 384.

Danforth, W. (1953). Oxidative metabolism of Euglena. Arch. Biochem. 46, 164.

Dean, A. C. R. \& Hinshelwood, Sir CYrIL (I959). Automatic adjustment mechanisms in bacterial cells. In Regulation of Cell Metabolism. Ed. by G. E. W. Wolstenholme and C. M. O'Connor. Boston: Little, Brown and Company.

GoA, J. (1953). Microbiuret estimation of protein. Scand. J. Clin. Lab. Invest. 5, 218.

Gray, C. T., Wimpenny, J. W. T., Hughes, D. E. \& Mossman, M. R. (I966). Regulation of metabolism in facultative bacteria. I. Structural and functional changes in Escherichia coli associated with shifts between the aerobic and anaerobic states. Biochim. biophys. Acta Ir7, 22.

HeINRICH, B. \& CoOK, J. R. (I967). Studies on the respiratory physiology of Euglena cultured on acetate or glucose. J. Protozool. (in the Press.)

Hugh, R. \& LeIfson, E. (1953). The taxonomic significance of fermentative versus oxidative metabolism of carbohydrates by various Gram-negative bacteria. J. Bact. 66, 24 .

Hutchens, J. O. (194I). The effect of the age of the culture on the rate of oxygen consumption and the respiratory quotient of Chilomonas paramecium. J. cell. comp. Physiol. 17, $32 \mathrm{I}$.

Kornberg, H. L. (1959). Aspects of terminal respiration in microorganisms. A. Rev. Microbiol. r3, 49.

Lowry, O. H., Rosebrough, N. J., Farr, A. L. \& Randall, R. J. (I95I). Protein measurement with the Folin phenol reagent. J. biol. Chem. 193, 265.

MAZIA, D. (196I). Mitosis and the physiology of cell divsion. In The Cell, Ed. by J. Brachet and A. E. Mirsky. Vol. 3. New York: Academic Press.

OGuR, M. \& Rosen, G. (1950). The nucleic acids of plant tissues. I. The extraction and estimation of deoxypentose nucleic acid and pentose nucleic acid. Arch. Biochem. 25, 262.

Prescott, D. M. (1957). Change in the physiological state of a cell population as a function of culture growth and age (Tetrahymena geleii). Expl Cell Res. 12, I26.

Pringsheim, E. G. \& Wiessner, W. (1960). Photo-assimilation of acetate by green organisms. Nature, Lond. $\mathrm{x88,} 919$.

Schmidt, G. \& Thannhauser, S. J. (1945). A method for the determination of deoxyribonucleic acid, ribonucleic acid, and phosphoproteins in animal tissues. J. biol. Chem. 16r, 83.

Swann, M. M. (1957). The control of cell division: a review, I. General mechanisms. Cancer Res. I7, 727.

WiLson, B. W. \& DANForTh, W. F. (1958). The extent of acetate and ethanol oxidation by Euglena gracilis. J. gen. Microbiol. 18, 535.

WILSON, B. W. \& LEVEDAHL, B. H. (1964). Synthetic and divisions rates of Euglena gracilis grown in batch cultures. Expl Cell Res. 35, 69.

Wilson, B. W., Buetow, D. E., JAHN, T. L. \& LeVedahl, B. H. (1959). A differential effect of pH on cell growth and respiration. Expl Cell Res. 18, 454. 